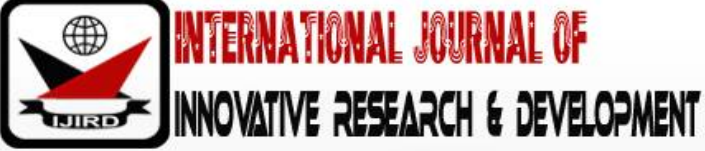

ISSN 2278 - 0211 (Online)

\section{Effect of Social Media Use on Guests' Post Purchase Evaluation and Loyalty in Four and Five Star Hotels Kenya: Quantitative Approach}

\author{
Elizabeth Ockeyoh Otieno \\ Lecturer, Department of Eco-Tourism, Hotel and Institution Management, Maseno University, Kenya \\ Dr. Billy Indeche Wadongo \\ Lecturer, Department of Eco-Tourism, Hotel and Institution Management, Maseno University, Kenya \\ Dr. Erick V. O. Fwaya \\ Lecturer, School of Tourism, Hospitality and Leisure Studies, Maasai Mara University, Kenya
}

\begin{abstract}
:
Demand for quality hotel service has led to adoption of information and communication technologies. Lately, online social media has revolutionized communication, post purchase evaluation and the marketing of tourism industry. Despite the contribution of social media in hotel business, the extent of its use by hotels in Kenya for guests' transactions has not been established. Moreover, the extent to which guests use social media for their hotel transactions remains unexplored. Guests' post purchase evaluation and loyalty further influence hotel performance, yet information on them is not well documented. The purpose of this study therefore was to determine the mediating effect of social media use on guest's post purchase evaluation and loyalty in 4 and 5 star hotels in Kenya. The population comprised of 3644 guests and 68 top managers in 4 and 5 star hotels in Nairobi and Mombasa where there is highest concentration of the hotels as well as hotel bed space of 3644 based on the year 2015 bed occupancy rate calculated at 40\% and 31\% for Nairobi and Mombasa respectively. Krejcie and Morgan formula was used to determine a sample of 362 guests and top managers. This study employed multi - stage random sampling technique. Both questionnaires and interview schedules were used to collect data. Quantitative analysis revealed that Social media use had partial mediating effect on the relationship between post purchase evaluation dimensions and guest loyalty i.e. Purchase importance (beta difference $=0.133$ ), Service performance (beta difference $=0.034$ ) and Information sharing (beta difference= 0.283). The study concluded that Social media use had a mediating effect on the relationship between guests' post purchase evaluations and guests' loyalty. The study recommended that stakeholders in the hotel industry should monitor and control social media use since it mediates the relationship.
\end{abstract}

Keywords: Social media, post purchase evaluation, guest loyalty, hotel industry, mediating

\section{Introduction and Theoretical Background}

The social media refers to a form of electronic communication and web sites for social networking and blogging through which users create online communities to share information, ideas, personal messages and other content (Merriam-Webster Dictionary, 2016). Networking, on the other, hand is the exchange of information or services among individuals, groups or institutions, specifically the cultivation of productive relationships for employment or business (Merriam-Webster Dictionary, 2016). Meanwhile, the internet is the global system of interconnected computer networks used to link billions of devices worldwide (Zieng et al, 2009). Nonetheless, Zieng et al, (2009) observed that the internet has fundamentally reshaped the way in which tourism related information is distributed and the way people plan for and consume travel. The social media can adequately provide a good medium for increasing business volume and guest loyalty in hotels. Chan and Gullet, (2011) however observed that hotels do not use the social media effectively to learn about their guests. Nevertheless, there is limited information on the extent to which hotels in Kenya including 4 and 5 star hotels use the social media to transact with their guests. Tourism stakeholders outside Kenya have recognized the social media as an important source of information for travellers (Naylor R.W., Lamberton, C.P. and West P.M. (2012). Neylor et al (2012) explain that consumers are increasingly relying on the social media to learn about unfamiliar brands. Similarly, hotels have attempted to use the internet, for example, to book in their guests and manage the guest cycle, but studies show that the hotels need to seek ways of assessing the extent to which their guests use the social media since more travellers are now using social media sites like Trip Advisor and Facebook to choose their hotels (World Travel Market (2011) Industry Report. Moreover, social media potential as a technology is yet to be exploited by more than half the population in other parts of the world e.g. in Hong Kong, Leung et al, (2013).Leung et al, (2013) further observed that the social media can be used widely by travellers to search, organize, share and annotate their travel stories and experiences (Leung et al, 2013). The social media can become a major influencer of consumers' purchase decision making processes, increase awareness, 
facilitate sharing of information, and influence the formation of opinions, attitudes, purchase and evaluation of post purchase experiences by guests who use the media (Kwok and Yu, 2013). Kwok et al, (2013) further observed that travellers are more likely to trust the messages and comments posted by other consumers on social media websites as compared to those reviewed by travel agent websites. Despite this, studies on hotels in Kenya including 4 and 5 star hotels, have directed very little attention to investigating the extent to which their guests use the social media in their hotel transactions. Post purchase evaluation plays an important role in customers' repeat purchase decisions (Muggee, Hendrick, Scefferstein \& Schoomans, 2010). The customers' tendency to replace their products and services depends on their experiences with, and feelings towards the old product or service (Muggee et al, 2010). Nonetheless, there is little information on the post- purchase evaluation experiences of guests in hotels including 4 and 5 star hotels in Kenya. Guest loyalty is another integral part of doing business since no business can survive without establishing a loyal customer base (Muggee et al, 2010). This makes customer loyalty a dominant factor in an organization's success (Kandampuly et al, 2002). However, little has been documented about guest loyalty in four and five star hotels in Kenya.

Social media websites also facilitate consumers in posting and sharing their travel related comments, opinions and personal experiences which then provide information to other stakeholders including other customers (Xieng et al, 2009). The social media via the internet can therefore be an effective promotional tool for hotels which want to increase their business volumes and enhance guest's post - purchase evaluation and loyalty. Nevertheless, the direct effects of use of social media and its mediating role in the relationship between guests' post purchase evaluation and loyalty in 4 and 5 star hotels in Kenya remains unexplored. This study, therefore, posits that the use of social media by guests and hotels will enhance communication between the guests and the hotels as well as amongst the guests themselves. The study further notes that, despite the significance of social media as a tool for effective communication within hotels, its potential is yet to be exploited within hotels in the rest of the world, especially within 4 and 5 star hotels in Kenya. This study therefore proposes to investigate the mediating effect of the social media on guests' post purchase evaluation and loyalty in 4 and 5 star hotels in Kenya.

\subsection{Statement of the Problem}

The social media can affect the consumers' purchase decision making process by influencing the customer's post purchase evaluation experiences and loyalty. The internet has reshaped the way tourism related information is distributed and the way people plan for and consume travel. New marketing communication tools nonetheless present new challenges and opportunities for companies because purchase decisions are increasingly being influenced by social media interactions. Moreover, people rely more on their social networks when making their purchase decisions. However, the extent to which the social media is used by 4 and 5 star hotels in Kenya for their guests' transactions has not been established. Similarly, the extent to which the guests in these hotels use the media for their hotel transactions remains unexplored. Guests' post- purchase evaluations and guest loyalty further influence hotel performance, yet information on guests' post purchase evaluation experiences and guest loyalty in 4 and 5 star hotels in Kenya is not well documented. Moreover, use of social media affects guests' post- purchase evaluations and loyalty in hotels. Nevertheless, the effects of social media campaigns on consumers' perceptions of the hotels' products and brands as reflected by their post - purchase evaluation decisions and loyalty particularly in Kenyan hotels remains unclear. The effects of use of social media on guests' post - purchase evaluation and loyalty in 4 and 5 star hotels in Kenya needed to be established. This study therefore investigated the mediating effect of the use of social media on guests' post- purchase evaluation and loyalty in 4 and 5 star hotels in Kenya.

\subsection{Purpose of the Study}

This study determined the mediating effect of social media use on guest's post purchase evaluation and loyalty in 4 and 5 star hotels in Kenya.

\section{Theoretical Literature Review}

\subsection{Social Exchange Theory}

The social exchange theory originated from sociology studies exploring exchange between individuals or small groups (Emerson 1976). The theory mainly uses a cost benefit framework and comparison of alternatives to explain how human beings communicate with each other, how they form relationships and bonds, and how communities are formed through communication exchanges (Homans 1958) The theory states that individuals engage in behaviors they find rewarding and avoid behaviors that have too high a cost. In other words, all social behavior is based on each actor's subjective assessment of the cost-benefit of contributing to a social exchange. They communicate or exchange with each other contingent on reciprocal actions from the other communicating party (Emerson 1976). The mutual reinforcement could be analyzed through a micro-economic framework, though the rewards are often not monetary but social, such as opportunity, prestige, conformity, or acceptance, Emerson (1976). This theory is supported by Homans (1958, p. 606) who arguably summarized it when he wrote: "Social behavior is an exchange of goods, material goods but also non-material ones, such as the symbols of approval or prestige. Persons that give much to others try to get much from them, and persons that get much from others are under pressure to give much to them. This process of influence tends to work out at equilibrium to a balance in the exchanges. For a person in an exchange, what he gives may be a cost to him, just as what he gets may be a reward, and his behavior changes less as the difference of the two, profit, tends to a maximum. Hence, the reasons why people engage in a social exchange have been posited as a) an expected gain in reputation and influence on others; b) an anticipated reciprocity on the part of others; c) altruism; and d) direct reward. Given that participation in the 
social media is not compensated, the first three reasons appear to have particular relevance to why people participate in social media"

\subsection{Social Media Use}

Social media generally refers to web applications that allow for the user to post and share content (Lange-Faria, and Elliot, 2012). Faria et al, (2012) have further established that common social media applications include Facebook, Twitter, Flickr and MySpace and that others include blogs, special collaborative projects, content communities and virtual game worlds. Faria et al, (2012) further noted that social media applications have been organized into domains such as expressing, networking, sharing and gaming. Consumer socialization through peer communication using social media websites has become an important marketing issue through the development and increased popularity of the social media (Xi Wang Chunling Yu and Yujie Wei, 2012). Moreover, online consumer socialization through peer communication also directly affects purchase decisions by conformity with peers and indirectly by reinforcing product involvement (Xi Wang et al, 2012). In addition, consumer's need for uniqueness has a moderating effect on the influence of peer communication on product attitudes (Wang et al, 2012) Other studies by Hutter, Dennhards and Fuller, (2013) observed that new marketing communication reality presents new challenges and opportunities for companies as purchases are increasingly influenced by the social media interactions.

\subsection{Post - Purchase Evaluations}

Post - purchase evaluations have been described as comparisons that customers make during ownership of a product/service (Muggee et al, 2010). Muggee et al, (2010) have observed that post - purchase evaluations play an important role in replacement purchases and that consumers' tendency to replace the product/ service they own by purchasing a new one depends on their experience with and feelings towards the old product or service. Fisher, Gardiald, Clemons, Wooodraff, Schumannand Burns (1994) established that throughout the consumption circle, from pre - purchase considerations of alternatives to choose consumption, customers evaluate products and services. Customers' post purchase behavior refers to all behavior, positive or negative, that is generated from the purchase (Kotler, Amstrong, Saunders \& Wong, 2003). Kotler et al, (2003) also established that cognitive dissonance, which is a buyer's thought shortly after a purchase, concerns whether the decision to purchase was right or wrong. They also observed that the outcome of evaluations can either be positive or negative.

\subsection{Guest Loyalty}

Guest loyalty has been defined as the relationship between relative attitude towards an entity (brand/ service/store/vendor) and patronage behavior, (Yaser Fahim Al-abdi, 2010). Yaserand Al-abdi, (2010) also observed that, as a concept, customer loyalty can be conceptualized in different perspectives and with a wide variety of classifications. Kandampuly et al, (2000) have described a loyal customer as one who repurchases from the same service provider whenever possible and who continues to recommend or maintain a positive attitude towards the service provider. Kandampuly et al, (2000) further established that there are two dimensions of customer loyalty: behavioral and attitudinal and that the behavioral dimension refers to a customer's behavior on repeat purchases, indicating a preference for a brand or service over time while attitudinal dimensions refer to a customer's intention to repurchase and recommend. They have recommended that both behavioral and attitudinal dimensions are good indicators of a loyal customer and that a customer who has the intention of repurchasing and recommending is very likely to remain with the company. A study by Dimitrades (2006) reported similar findings but established a composite perspective as a third dimension. This author suggested that the behavioral perspective (purchase loyalty) strictly looks at repeat purchase history, based on the customers' purchase history whereby the emphasis is on future actions. Dimitrades, (2006) further noted that the attitudinal perspective, in contrast, allows gain in supplemental understanding of loyal behavior where customer loyalty is approached as an attitudinal construct. The author further suggested that attitude denotes the degree to which a customer's disposition towards a service is favorably inclined. The author posits that this inclination is affected by activities such as customers recommending service providers to others or commitment to re - patronize. The composite perspective might be considered as an alternative to affective loyalty since both attitude and behavior in a loyalty definition arguably increase the predictive power of loyalty. Customer loyalty expresses an intended behavior related to the service or the company. This includes the following: the likelihood of future renewal of service contracts, how likely the customer is to provide positive word of mouth and the likelihood of the customers providing voice or to exit (Andreason and Lenderstad, 1998). Voice and exit are two feedback mechanisms where exit implies that the customer would stop buying the company's services while voice is the customer's complaint expressing their dissatisfaction directly to the company (Andreason and Lenderstad, 1998).

\section{Methodology}

This study employed a concurrent triangulation strategy which collects data in two phases and integrates it during interpretation or analysis where convergence or lack of it strengthens knowledge and can be confirmed, corroborated or cross validated within a single study (Terrell, 2012). This is shown in Figure 1 


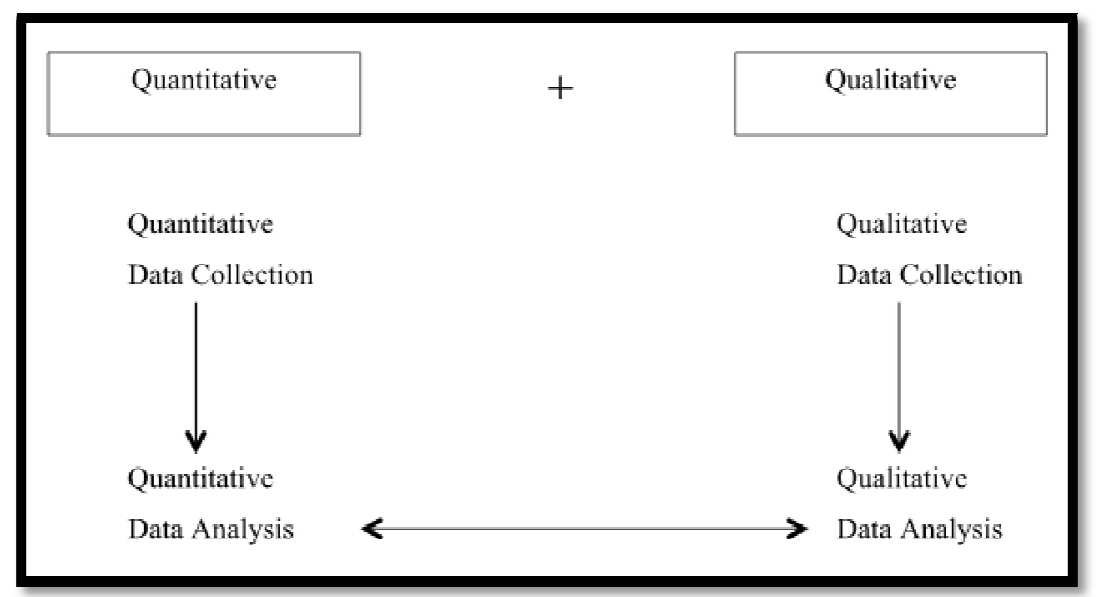

Figure 1: Concurrent Triangulation Strategy: Source: Terrell, (2012)

This study focused on star rated hotels in Kenya and was conducted within four and five star hotels in Nairobi and Mombasa. Nairobi and Mombasa were specifically selected because they have the highest number of four and five star hotels as well as the highest concentration of hotel bed space. The Kenya Association of Hotel Keepers and Caterers (KAHK\&C, 2016), a body that classifies member hotels according to the available bed spaces as well as their ratings, noted that Nairobi has the highest number of four and five star hotels followed by Mombasa (KHK\&C, 2016).

\subsection{Population and Selection Criteria}

Table 1illustrates the selection criteria that was used to estimate guest population (3644) for this study based on $40 \%$ bed occupancy rate in 4 and 5 star hotels in Nairobi and 31\% in Mombasa. The bed occupancy rates for both Nairobi and Mombasa were based on statistical data and economic survey by Kenya National Bureau of Statistics (KNBS), 2015. According to KNBS's statistical data (2015), bed occupancy rates in 2013 were 43.2\% in Nairobi high class hotels and 37.3 in Mombasa Island and coastal beach hotels. This, however, reduced in 2014, where Nairobi recorded 40\% while Mombasa had 31\%. The drop in (BOR) between 2013 and 2014 was due to a reduced international visitor arrival attributed to the tourism sector's suppressed performance which was caused by security concerns due to terrorism threats, negative travel advisories and the Ebola outbreak in 2014 (KNBS, Economic Survey, 2016). This study used the (BOR) for the year 2015 to calculate the guest sample size for this study where Nairobi hotel rates were calculated at $40 \%$ and Mombasa at $31 \%$.

\begin{tabular}{|c|c|c|c|c|}
\hline & NO. of Hotels & Total Bed space & Bed Occupancy Rate & Actual \\
\hline Nairobi & & & & \\
\hline 5 Star & 20 & 3217 & 1286.8 & 1287 \\
\hline 4 Star & 16 & 1583 & 633.2 & 633 \\
\hline Mombasa & & & & \\
\hline 5 Star & 11 & 1770 & 548.7 & 549 \\
\hline 4 Star & 21 & 3788 & 1174.28 & 1175 \\
\hline Total & 68 & 10358 & 3642.98 & 3644 \\
\hline
\end{tabular}

Table 1: Selection of Hotel Guests in Nairobi and Mombasa Four and

Five Star Hotels Using Bed Occupancy Rate

As indicated in Table 1guests population was 3644 while top managers were 68, giving a total population of 3712 .

\subsection{Sample Size and Sampling Technique}

The study employed multi - stage sampling technique where stratified and simple random sampling were used. According to Elder (2009), multi-stage sampling is also referred as combined sampling which can be done in several steps. Since the region where a hotel may be placed has an influence on the outcome variable, the first stratification was based on the region where the hotel is found thus the hotels were first divided into regions of Nairobi and Mombasa as shown in Table 1.1

In order to determine the study sample size, Krejcie and Morgan (1970) table was used. The sample size was therefore 346. The response from the field exceeded the minimum expected sample size by 16 respondents and the researcher used all the responses giving a total of 362 as the new sample size used.

\subsection{Data Collection and Interpretations}

This study used questionnaires and interview guides as data collection instruments.

To analyze the data, the following hierarchical models were used:

The model for objective three was:

$\mathrm{Y}_{3 \mathrm{i}}=\beta_{30}+\beta_{31} \mathrm{PI}_{1 \mathrm{i}}+\beta_{32} \mathrm{SP}_{2 \mathrm{i}}+\beta_{33} \mathrm{IS}_{3 \mathrm{i}}+\epsilon_{3 \mathrm{i} . \ldots}$

Where:

$\mathrm{Y}_{3 \mathrm{i}}$ - Social Media Use

$\mathrm{B}_{30}, \beta_{31}, \beta_{32}, \beta_{33}$ - Constants to be determined 
$\mathrm{PI}_{1 \mathrm{i}}$ - Purchase Importance

$\mathrm{SP}_{2 \mathrm{i}}$ - Service Performance

IS $_{3 \mathrm{i}^{-}}$Information Sharing

$\epsilon_{3 \mathrm{i}}-$ error term

$\mathrm{Y}_{4 \mathrm{i}}=\beta_{40}+\beta_{41} \mathrm{PI}_{1 \mathrm{i}}+\beta_{42} \mathrm{SP}_{4 \mathrm{i}}+\beta_{43} \mathrm{IS}_{4 \mathrm{i}}+\epsilon_{4 \mathrm{i} . .}$

Where: $\quad Y_{4 i}$ - Guest Loyalty

$\mathrm{B}_{40}, \beta_{41}, \beta_{42}, \beta_{43^{-}}$- Constants to be determined

$\mathrm{PI}_{1 \mathrm{i}}$ - Purchase Importance

$\mathrm{SP}_{2 \mathrm{i}}$ - Service Performance

IS $_{3 \mathrm{i}}$ - Information Sharing

$\epsilon_{4 \mathrm{i}}-$ error term

$Y_{5 i}=\beta_{50}+\beta_{51} \mathrm{PI}_{1 \mathrm{i}}\left(\mathrm{Y}_{3 \mathrm{i}}\right)^{-1}+\beta_{52} \mathrm{SP}_{4 \mathrm{i}}\left(\mathrm{Y}_{3 \mathrm{i}}\right)^{-1}+\beta_{53} \mathrm{IS}_{4 \mathrm{i}}\left(\mathrm{Y}_{3 \mathrm{i}}\right)^{-1}+\epsilon$

Where: $\quad Y_{5 i}-$ Guest Loyalty

$\mathrm{B}_{50}, \beta_{51}, \beta_{52}, \beta_{53}$ - Constants to be determined

$\mathrm{PI}_{1 \mathrm{i}}$ - Purchase Importance

$\mathrm{SP}_{2 \mathrm{i}}$ - Service Performance

IS $_{3 \mathrm{i}}$ - Information Sharing

$\left(\mathrm{Y}_{3 \mathrm{i}}\right)^{-1}$ - The mediating effect of Social Media Use on Post Purchase Evaluation elements

$\epsilon_{4 \mathrm{i}}$ - error term

3.4. Results of Mediating Effect of Social Media Use on Post Purchase Evaluation and Guest Loyalty

The study sought to establish the mediating role of social media use on the relationship between guests' post purchase evaluations and loyalty in $4 \& 5$ star hotels in Nairobi and Mombasa, Kenya.

The procedure for establishing the mediating role was undertaken through three steps:

- Step 1: Regression of the Independent Variable on Mediator variable.

- Step 2: Regression of the Independent variable on dependent variable.

- Step 3: Regression of both the independent variable and the mediator variable on the dependent

Upon regressing both the independent variable and the mediator variable on the dependent variable, the results obtained are in Table 2 and 4.8 below:

\begin{tabular}{|c|c|c|c|c|}
\hline Model & $\mathbf{R}$ & $\begin{array}{c}\mathbf{R} \\
\text { Square }\end{array}$ & $\begin{array}{c}\text { Adjusted R } \\
\text { Square }\end{array}$ & $\begin{array}{c}\text { Std. Error of the } \\
\text { Estimate }\end{array}$ \\
\hline 1 & $.137 \mathrm{a}$ & .019 & .011 & .623708 \\
\hline \multicolumn{4}{|r}{} \\
\hline
\end{tabular}

Table 2: Model Summary

a. Predictors: (Constant), INFOSHARING, SERVPERF, PIMPORTANCE

From the above Table 2 , it was revealed that the $\mathrm{R}^{2}=0.019$. This implies that only $1.9 \%$ of the variability in the dependent variable is explained by the variability in the predictor variable.

\begin{tabular}{|c|c|c|c|c|c|c|}
\hline \multicolumn{2}{|c|}{ Model } & \multicolumn{2}{c|}{$\begin{array}{c}\text { Unstandardized } \\
\text { Coefficients }\end{array}$} & $\begin{array}{c}\text { Standardized } \\
\text { Coefficients }\end{array}$ & \multirow{2}{*}{ t } & \\
\cline { 3 - 6 } \multicolumn{2}{|c|}{} & $\mathrm{B}$ & Std. Error & Beta & & \\
\hline \multirow{3}{*}{1} & $($ Constant $)$ & 1.533 & .261 & & 5.884 & .000 \\
\cline { 2 - 7 } & $\mathrm{PI}\left(\mathrm{Y}_{3 \mathrm{i}}\right)^{-1}$ & -.010 & .058 & -.013 & -.180 & .857 \\
\cline { 2 - 7 } & $\mathrm{SP}\left(\mathrm{Y}_{3 \mathrm{i}}\right)^{-1}$ & .037 & .061 & .042 & .604 & .546 \\
\cline { 2 - 7 } & $\mathrm{IS}\left(\mathrm{Y}_{3 \mathrm{i}}\right)^{-1}$ & .135 & .059 & .127 & 2.302 & .022 \\
\hline
\end{tabular}

Table 3: Regression Results

Dependent Variable: GUESTLTY

From Table 3 above, it is clear that Purchase Importance and Social Media use had an insignificant weak negative influence on Guest Loyalty $(\beta 1=-0.013, P>0.05)$. This implies that Purchase Importance and Social media use have inverse influence on Guest loyalty.

Service performance and social media use were found to have a weak insignificant positive influence on Guest loyalty $(\beta 2=0.042, P>0.05)$. This means that whenever service performance and social media use are implemented together in hotels, then there would be slight positive increase in Guest loyalty.

Information sharing and social media use were found to have a significant positive influence on Guest loyalty $(\beta 3=0.127, \mathrm{P}<0.05)$. This implies that whenever hotels invest on information sharing and social media use, there would be a significant increase in Guest loyalty. 


\begin{tabular}{|c|c|c|c|c|c|c|}
\hline $\begin{array}{c}\text { Dependent } \\
\text { Variable: } \\
\text { Guest Loyalty }\end{array}$ & $\begin{array}{c}\text { Independent } \\
\text { Variable }\end{array}$ & $\begin{array}{c}\text { Step 1 } \\
\text { Beta }\end{array}$ & $\begin{array}{c}\text { Step 2 } \\
\text { Beta }\end{array}$ & $\begin{array}{c}\text { Step 3 } \\
\text { Beta }\end{array}$ & $\begin{array}{c}\text { Step 2 and Step 3 } \\
\text { Beta difference }\end{array}$ & $\begin{array}{c}\text { Type of } \\
\text { effect }\end{array}$ \\
\cline { 2 - 7 } & $\begin{array}{c}\text { Purchase } \\
\text { Importance }\end{array}$ & 0.400 & 0.120 & -0.013 & 0.133 & Partial \\
\cline { 2 - 7 } & $\begin{array}{c}\text { Service } \\
\text { Performance }\end{array}$ & 0.541 & 0.076 & 0.042 & 0.034 & Partial \\
\cline { 2 - 7 } & $\begin{array}{c}\text { Information } \\
\text { Sharing }\end{array}$ & 0.298 & 0.410 & 0.127 & 0.283 & Partial \\
\cline { 2 - 6 } & \multicolumn{7}{|c|}{ Mediator: Social Media Use } \\
\hline
\end{tabular}

Table 4: The Summary for Mediating Effect of Social Media Use on the

Relationship between Post Purchase Evaluation and Guest Loyalty

To test the significance of mediation effect, the conservative Sobel Goodman test was employed (Sobel 1982). From Table 4 above, the study established that social media use had partial mediation effect on the relationship between the three dimensions of post purchase evaluation and guest loyalty i.e. Purchase importance and guest loyalty (beta difference $=0.133$ ), Service performance and guest loyalty (beta difference $=0.034$ ) and Information sharing and guest loyalty (beta difference $=0.283$ ).

The findings that social media use partially mediates the relationship between guests' post purchase evaluation and loyalty support the findings by Ida, Werdiningsih, Djumilah, Luh and Fatchur (2013) who studied service quality influence on patient loyalty: Customer relationship management as mediation variables and established that, service quality influenced customer loyalty positively and significantly and that implementation of customer relationship management (CRM) mediated service quality influence on customer loyalty.

The findings further support those of Xi Y. Leung Billy Bai Kurt A, Stahura (2013) who established that hotel customers' social media experiences influence their attitudes toward social media site which in turn influence their attitudes towards the hotel brand. Xi et al, (2013) further noted that hotel customers' attitudes towards hotel brand affected their booking intentions and in turn their intentions to spread electronic word of mouth. This suggests that social media experiences with hotel brand would positively influence their positive evaluation of the hotel through word of mouth.

\section{Conclusion}

Based on the findings that social media use had partial mediation effect on the relationship between post purchase evaluation and guest loyalty, the study concluded by not accepting the null hypothesis that stated that "Social media use does not have a mediating role on the relationship between guests' post - purchase evaluation and loyalty in $4 \&$ 5 star hotels in Nairobi and Mombasa, Kenya".

\section{Recommendation}

Based on the conclusion that Social media use had a mediating effect on the relationship between guests' post purchase evaluation and loyalty in $4 \& 5$ star hotels in Nairobi and Mombasa, Kenya, the study recommends that hotel management should invest more, monitor and control social media use since it facilitates the relationship between guests' post purchase evaluation and loyalty.

\section{References}

i. Al-abdi Yaser Fahmi (2010) A Three-Dimensional Customer Commitment Model: It's Impact on Relational Outcomes. A Ph.D. Thesis. University of Manchester Journal of Travel Research

ii. Andreason Tor William and Bodil Lenderstand (1998). The Impact of corporate Image on quality Customer Satisfaction and Loyalty for Customers with varying degrees of Service Expertise. International Journal of Service Industry Management Vol. 9. No 1 pp. 7 - 23.

iii. Chan, N. L., \& Guillet, B. D. (2011). Investigation of Social Media Marketing: How Does the Hotel Industry in Hong Kong Perform in Marketing on Social Media Websites? Journal of Travel \& Tourism Marketing, 28(4), 345-368. doi: 10.1080/ 10548408.2011.571571

iv. Dimitrriades Zoe S. (2006) Customer Satisfaction, Loyalty and Commitment in Service Organizations, some evidence from Greece. University of Macedonia, Thessalonik, Greece. Management Research New. Vol.29 No.12, pp782-800

v. Emerson, R. (1976). Social exchange theory. Annual Review of Sociology, 335-362.

vi. Fisher Sarah Gardial, D. Scott Clemons, Robert B. Woodruff, David W. Schumann, Mary

vii. Jane Burns (1994) Comparing Consumer's Recall of Pre-Purchase and Post purchase product evaluation experiences. Journal of consumer Research Inc. Vol.20 pp548-560

viii. Homans, G. 1958. Social behavior as exchange. American Journal of Sociology, 63(6), 597-606.

ix. Hutter Katja, Julia Hautz, Severin Denhardt and Johann Fuller (2013). The Impact of User Interactions in Social Media on Brand Awareness and Purchase intentions: The Case of MINI on Facebook. Journal of Product \& Brand Management Vol. 22ISS 516 pp. 342- 351

x. Ida, A., Werdiningsih, K., Djumilah, H., Ni Luh, P. \& Fatchur, R. (2013). Service Quality Influence on Patient Loyalty: Customer Relationship Management as a Mediation Variable (Study on Private Hospital Industry in

xi. Denpasar). International Journal of Business and Commerce Vol. 2, No.12: Aug 2013[01-14] 
xii. Kenya Association of Hotelkeepers \& Caterers. (2016)

xiii. Kenya National Bureau of Statistics (2015) Statistical Abstract.

xiv. Kenya National Bureau of Statistics, Economic Survey, (2016)

xv. Kandampuly Jay and Dwi Suhartanto (2002) Customer Loyalty in the Hotel Industry: The Role of Customer Satisfaction and Image. International Journal of Contemporary Hospitality Management. 12/ 6346 - 351

xvi. Kwok Linchi and Bei Yu (2013) Spreading Social Media Messages on Facebook: An Analysis of Restaurant Business to Consumer Communications. Cornell Hospitality Quarterly pp54 (1) 84-94

xvii. Kotler Phillip, Gray Amstrong, John Saunders \& Veronica Wong (2003) Principles of

xviii. Marketing. ISEDE and Prentice Hall International ISBN

xix. Lange Wendy - Faria and Statia Elliot (2012). Understanding the role of Social Media in destination Marketing Tourism: An International Multidisciplinary Journal of Tourism. Vol 7 no. 1 pp 193 - 211

xx. Leung, D, Rob L, Hubert V and Dimitrios B. (2013) Social media Tourism and Hospitality: A Literature Review. Journal of Travel \& Tourism Marketing Vol. 30: 1-2, 3-22

xxi. Merriam - Webster Dictionary, (2016)

xxii. Micharl E. Sobel, (1982). Asymptotic Confidence Intervals for Indirect Effects in Structural Equation models. Sociological Methodology, vol. 13 pp.290 - 312. Willey Publishers

xxiii. Muggee Ruth, Hendrick P.L. Schifferstein and Jan P.L. Schoormans (2010) Product attachment and Satisfaction: Understanding Consumer's Post Purchase Behavior. Journal of Consumer MarketingVol. 27/ 3 pp271-282

xxiv. Naylor, R.W., Lamberton, C, P and West, (2012). Beyond the like' button - The Impact of mere Virtual Presence on Brand Evaluation and Purchase Intentions in Social Media Settings. Journal of Marketing, 76 (6), 105 - 120

xxv. Robert V. Krejcie and Davyle W. Morgan (1970) Determining Sample Size for Research Activities. Educational and Psychological Measurement, 607 - 610

xxvi. Terrell Steven R (2012) Mixed Methods Research Methodologies. The qualitative Report. Vol. 17 No. 1 pp. 254280. Nova, SouthEastern University. USA

xxvii. World Travel Market Industry Report (2011)

xxviii. Xi Y. Leung, Billy Bai Kurt A. Stahura (2013). The Marketing Effectiveness of Social Media in the Hotel Industry: A comparison of Facebook and Twitter. Journal of Hospitality \& Tourism Research, Vol 39, No 2, pp. 147 - 169

xxix. Xia Wang, Chunling Yu and Yujie Wei (2012). Social Media Peer Communication and Impacts on Purchase Intentions: A consumer Socialization Framework. Elsevier Publications

xxx. Yaser Fahmi Al-abdi (2010) A Three-Dimensional Customer Commitment Model: It's Impact on Relational Outcomes. A Ph.D. Thesis. University of Manchester Journal of Travel Research.

xxxi. Zheng Xiang, Ulrike Gretzel (2009). The Role of Social Media in Online Travel Information Search. Journal of Tourism Management Vol. 31 pp179 - 188 